\title{
Working
}

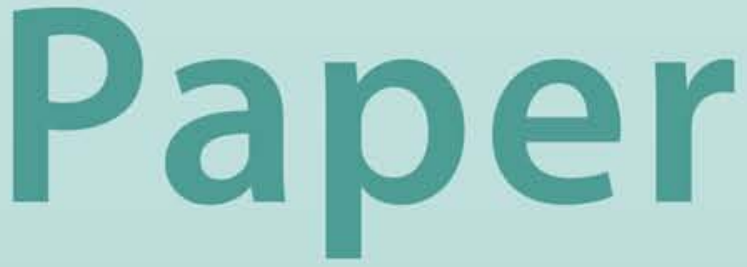


The Equilibrium Real Exchange Rate in a Commodity Exporting Country: The Case of Russia

Nikola Spatafora and Emil Stavrev 


\title{
IMF Working Paper
}

\author{
European II Department
}

\section{The Equilibrium Real Exchange Rate in a Commodity Exporting Country: The Case of Russia}

\author{
Prepared by Nikola Spatafora and Emil Stavrev ${ }^{1}$ \\ Authorized for distribution by David Owen
}

May 2003

\begin{abstract}
The views expressed in this Working Paper are those of the author(s) and do not necessarily represent those of the IMF or IMF policy. Working Papers describe research in progress by the author(s) and are published to elicit comments and to further debate.
\end{abstract}

Questions about external competitiveness, exchange rate misalignment, and the appropriate exchange rate policy feature prominently in the Russian policy debate. This paper furthers the debate by estimating empirically Russia's equilibrium real exchange rate (ERER) - that is, the rate consistent with the long-run economic fundamentals-and sheds light on the extent to which exchange rate policy should be changed.

The paper confirms that the ERER reflects both productivity and the terms of trade. It suggests that Russia should target a significant medium-term current account deterioration and a real appreciation perhaps exceeding 10 percent. However, this latter number remains very sensitive to the assumed long-run oil prices.

JEL Classification Numbers: F4

Keywords: real exchange rate, Russia

Authors’ E-Mail Addresses: nspatafora@imf.org; estavrev@imf.org

\footnotetext{
${ }^{1}$ We wish to thank William Buiter, Libor Krkoska, John Odling-Smee, Roman Zytek, and participants in seminars at the IMF and the European Bank for Reconstruction and Development (EBRD) for valuable discussions and comments.
} 


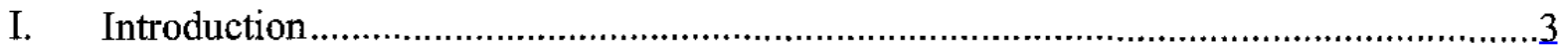

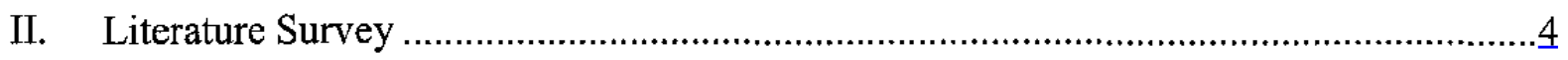

III. Analyzing Russia's Historical Experience: Methodology ……....................................

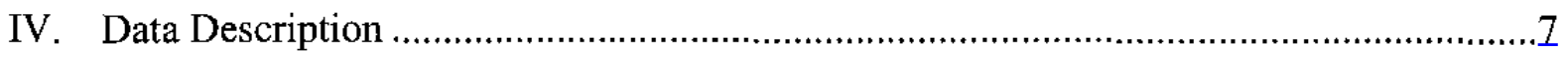

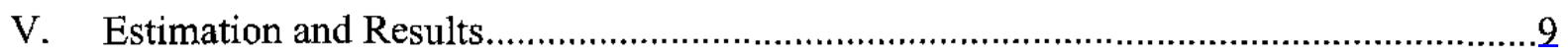

VI. Normative Approach: Lessons from the Experience of Other Economies.....................13

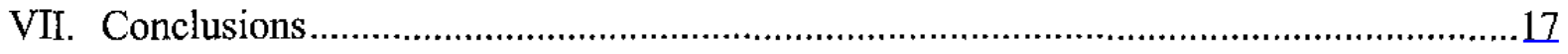

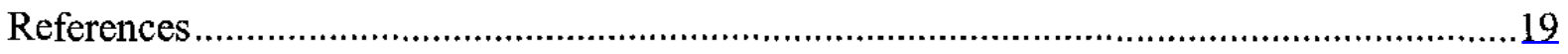

\section{Tables}

1. Change in Competitiveness Indicators, 1995-2002 ..............................................

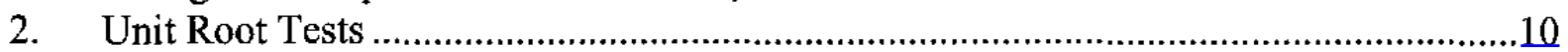

3. Long-Run Cointegrating Relationship............................................................

4. Real Exchange Rate in 2002: Percent Undervaluation, Under Various Assumptions ...16

\section{Figures}

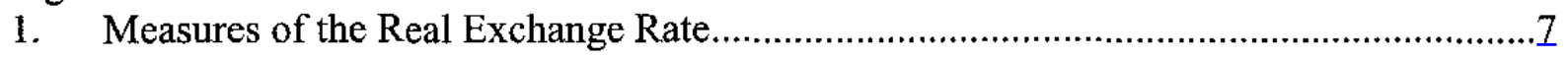

2. Urals Oil Prices and Real Effective Exchange Rate .....................................................

3. Relative Productivity and Real Effective Exchange Rate...........................................

4. Urals Oil Prices, Reserve Accumulation, and Real and Nominal Exchange Rates.......... 


\section{INTRODUCTION}

Over the last decade, Russia has been on an economic roller coaster. The start of transition saw a sharp output collapse and prolonged stagnation. This was followed by a tentative recovery in 1997 and a dramatic banking and exchange rate crisis in August 1998. During 1999-2002, a depreciated real exchange rate (RER), booming world prices for energy (Russia's key export), a tightened fiscal policy, and significant progress in key structural reforms led to high growth rates, a significant recovery in investment, unprecedented current account surpluses, and rising living standards.

Not surprisingly, there is much debate regarding the policies needed to sustain rapid growth and complete the transition. Questions about external competitiveness, exchange rate misalignment, and the appropriate exchange rate policy have featured prominently in this debate. Some observers note that the sharp real appreciation which accompanied the start of transition was eventually followed by a crisis and suggest that the rapid post-crisis recovery in the RER, unless strongly resisted, will also eventually endanger growth, employment, and fiscal and external sustainability. In contrast, the recent real appreciation has been accompanied by dramatic swings in the terms of trade and the external current account, and a considerable reduction in the non-oil government deficit. It is therefore quite possible that changes in the RER may have reflected movements in the underlying fundamentals, and indeed that further appreciation might be desirable.

Taking a somewhat broader perspective, exchange rate fluctuations can have significant effects, for at least two reasons. First, even short-term RER volatility can impose large welfare costs. Especially in a context of underdeveloped financial markets, where firms and households face cash-flow constraints, such volatility reduces the level of international trade, affects investment decisions, and hinders growth possibilities. Second, such welfare costs are magnified in the case of prolonged and sustained exchange rate misalignments, which can badly distort resource allocation.

From a policy standpoint, it is therefore critical both to understand the main determinants of the RER and to distinguish between short- and long-term RER movements. Macroeconomic policies can then be used to smooth "excessive" short-term changes and to correct any emerging misalignments.

An accurate analysis of the RER is particularly critical in resource-dependent and transition economies. Such economies often experience large shocks to fundamentals such as the terms of trade and productivity, and very unstable domestic policies. As a result, their RERs may be particularly prone to excess volatility and misalignment.

This paper uses empirical evidence both from Russia's experience since the beginning of transition, and from the experience of more advanced transition economies to estimate the determinants of Russia's RER, and its likely movements over the medium term. The analysis focuses on estimating the equilibrium RER - that is, the level of the RER consistent with a viable external position. Section II briefly summarizes the existing literature on equilibrium 
RER. Section III describes the methodology employed to analyze Russia's historical experience. Section IV discusses and describes the available data, including in particular different measures of the RER. Section V reviews the econometric results and derives the equilibrium RER. Section VI uses an alternative forward-looking approach, based on the experience of advanced transition economies and some resource exporters, to discuss the likely long-run equilibrium RER. Section VII concludes.

\section{LITERATURE SURVEY}

There is a substantial theoretical and empirical literature on the long-run equilibrium real exchange rate (ERER). In general, this is defined as the level of the RER which is consistent with both external equilibrium (i.e., a sustainable current account), and internal equilibrium (in the labor and goods market). Clark (1994), MacDonald (1995), Hinkle and Montiel (1999), and MacDonald and Stein (1999) provide a good summary of the concept of equilibrium RER and alternative competitiveness indicators.

Much of the literature has dealt with advanced economies. However, developing countries typically face different sets of structural issues, and a more limited availability of data. Edwards $(1986,1989,1994)$ made a seminal attempt to build an equilibrium exchange rate model specifically tailored to developing countries. Here, the ERER is defined as the relative price of non-tradables to tradables that results in the simultaneous attainment of internal and external equilibrium. The broad idea is to explore the long-run co-movements of the ERER with variables such as the terms of trade, productivity, net foreign assets, the fiscal balance, and measures of openness of the trade and exchange-system. The general finding is that the ERER tends to appreciate with increases in each of these variables.

Edwards' framework has been adapted and extended by several authors. Khan and Ostry (1991) provide panel data estimates of the elasticity of the ERER with respect to terms of trade shocks and commercial policies. Elbadawy (1994) develops a simplified version of the model, and used it to provide estimates of the ERER for Chile, Ghana, and India. More recent studies include Faruqee (1995), Mongardini (1998) for Egypt, De Broeck and Sløk (2001) for transition economies, Lane and Milesi-Ferretti (2002) for Ireland, and MacDonald and Ricci (2002) for South Africa.

Various refinements are possible on the basic approach. For instance, Lane and Milesi-Ferretti $(2001,2002 \mathrm{~b})$ suggest that the positive relationship between net foreign assets and the RER reflects a negative relationship between (a) net foreign assets and the trade balance, and (b) the trade balance and the RER. In a different vein, Clark and MacDonald (1999, 2000), as well as Feyzioglu (1997) for Finland, and Paiva (2001) for Costa Rica, extend the approach to better differentiate between permanent and transitory components of the RER.

All these approaches focus on changes in the ERER, but they may also yield insights about its level, so long as assumptions are made about which historical period actually constituted an equilibrium. Williamson (1994) pursues a slightly different, more forward-looking 
approach, postulating instead a normative target for the current account which in turn identifies the desirable ERER.

\section{ANALYZING Russia's Historical EXPERIENCE: Methodology}

We start by analyzing Russia's historical experience, following closely the methodology of Edwards (1994) and Mongardini (1998). In order to estimate the ERER, we construct a small structural model tailored to the Russian economy. The key idea is to decompose changes in the actual RER into permanent, fundamental changes, reflecting shocks to the ERER, and more transitory variations, reflecting inter alia shocks to monetary policy. So as to separate these short- and long-term factors, we will estimate a reduced-form equation in an error-correction form.

More formally, the structural equation for the ERER is:

$$
\ln e^{*}=\alpha_{0}+\alpha_{1} \ln F U N D_{t}+u_{t}
$$

where $e^{*}$ is the ERER, and $F U N D$ is the vector of fundamental variables, which in particular includes:

- The world price of Russian Urals oil. We expect an improvement in the external terms of trade to act to increase the current account balance, and hence appreciate the ERER. Since a terms-of-trade series for Russia is not available, we use as a proxy the price of Russian crude oil. This reflects the fact that exports of hydrocarbons, including oil, oil products, and natural gas, account for a substantial fraction of total Russian exports (over one-half in both 2000 and 2001). Further, oil accounts for most of the hydrocarbon exports, and the prices of other hydrocarbons seem to fluctuate in parallel with oil prices. ${ }^{2}$

- Industrial productivity in Russia, relative to its trading partners. Following the literature on the Balassa-Samuelson effect, we expect increased relative productivity in the economy, and in particular in the tradable sector, to lead to an appreciation of the ERER. We focus on industry, as a proxy for tradables, and examine its average labor productivity. In principle, we would like to use total factor productivity, but are unable to make the adjustment because data on the capital stock, capacity utilization, and labor quality is too unreliable and only available for a very limited sample.

\footnotetext{
${ }^{2}$ We tried constructing an aggregate price index for Russian energy exports, using a weighted average of Russian oil and natural gas prices, but this variable failed to improve on the simple Urals oil price.
} 
- Post-1998-crisis structural break dummy. We expect a negative coefficient on this dummy, reflecting two factors. First, any pre-crisis RER overvaluation. Second, the post-crisis RER undershooting.

In the short-run, we also assume that the actual RER adjusts towards the equilibrium at a speed given by the parameter $\beta$, but that changes in other variables, including in particular policy variables, may disturb the adjustment. Formally,

$$
\Delta \ln e_{t}=\beta\left(\ln e^{*}{ }_{t-1}-\ln e_{t-1}\right)+\gamma \ln \left(T E M P_{t} / T E M P^{*}\right)+v_{t}
$$

where $e$ is the actual RER, TEMP is a vector of variables having a transitory effect on the RER, and TEMP* is the vector of such variables that is consistent with the ERER. When specifying $T E M P$, we focus on the following policy variables:

- The excess growth in net international reserves. Specifically, we use the increase in the reserve cover, that is, the ratio of reserves to monthly imports. This reflects the argument that, especially since the crisis, the authorities may have tried to slow the pace of real appreciation by intervening in the foreign exchange market and building up reserves.

- $\quad$ The excess supply of domestic credit, that is, the increase in domestic credit that is unmatched by higher growth in the economy. Specifically, we use the increase in the ratio of ruble broad money to GDP. This is also an attempt to capture shocks to monetary and exchange rate policy.

- $\quad$ The increase in the fiscal deficit, relative to lagged high-powered money. A fiscal loosening may have (at least) two different effects. First, it may lead to increased spending on nontradables, raising their prices and putting upward pressure on the RER. Second, it may reduce confidence in the sustainability of fiscal, monetary, and exchange rate policy, provoking a reduction in capital inflows and a real depreciation. $^{3}$

Since theory does not restrict the precise short-run dynamics, we use standard information criteria to determine the lag length for these policy variables, and also include in TEMP lagged values of the various fundamental variables. ${ }^{4}$

\footnotetext{
${ }^{3}$ We tried including also a debt-stock variable, to capture separately this confidence effect, but received unsatisfactory results. Also, we tried allowing our fiscal variable to affect the ERER too, but received counter-intuitive results.

${ }^{4}$ We would have liked to include a measure of NFA among the fundamental variables. However, the Lane and Milesi-Ferretti (2001) NFA dataset does not include Russia. We did try including the measure of NFA reported in IFS, but this did not work satisfactorily, likely because of the various problems discussed by Lane and Milesi-Ferretti.
} 
Once the above model has been estimated, we can also perform a variance decomposition so as to study the sources of RER variability. In particular, this will give us a measure of how much of the variability in the RER is caused by changes in real variables such as the terms-of-trade and productivity.

\section{DATA Description}

We distinguish between two main definitions of the RER. First, we consider the external $R E R$ - defined as the nominal exchange rate adjusted for price level differences between countries. This measure compares the relative value of currencies by measuring either the relative prices of foreign and domestic consumption or production baskets, or else the relative input costs. We use the following measures of the external RER: the CPI-based effective RER, and the U.S. dollar value of industrial wages.

Second, we consider the internal RER - defined as the ratio of the domestic price of nontradables to tradables within a single country. This concept captures the internal relative price incentive for producing or consuming nontradables as opposed to tradables. As a proxy for nontradables we use paid services. As a proxy for tradables we use food items and other items from the CPI basket.

The external and internal measures of the RER show the same qualitative developments between 1995 and today. All measures of competitiveness appreciated sharply from the beginning of 1995 till the 1998 crisis, collapsed in the wake of the crisis, and have again appreciated strongly since (see Figure 1).

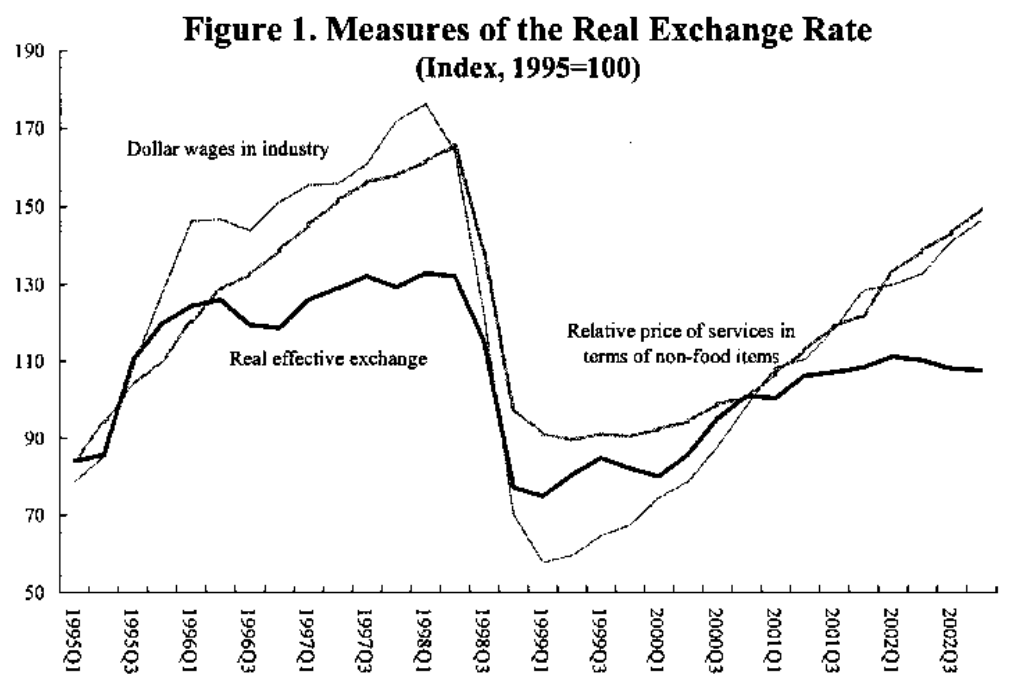

Dollar wages, and to a lesser extent the relative price of nontradables, have fluctuated much more widely than the CPI-based real effective exchange rate, owing to a combination of factors. Before the crisis, the much faster real appreciation of dollar wages reflected cost-push pressures against a background of rising competition from imports. The sharp real 
wage fall during the crisis reflected both nominal wage rigidities, and the fast pass-through from the nominal exchange rate to tradable prices. Finally, the very fast recovery in wages since the crisis is partly a response to their overshooting during the crisis.

Still, the difference between the pre-crisis level and the Q3 2002 level is broadly comparable across all three measures (see Table 3.1). The CPI-based REER is 18 percent below its pre-crisis level, while the other two measures are roughly 15 percent below their pre-crisis levels. Since all three measures give the same qualitative picture about developments in competitiveness, and suggest similar changes from pre-crisis levels, we focus in the rest of the paper on the CPI-based REER. However, we check the robustness of the results by also using the other two measures and comparing the results.

Table 1. Change in Competitiveness Indicators, 1995-2002

(In percent)

\begin{tabular}{lcccc}
\hline & & & Crisis & $\begin{array}{c}\text { Difference from the } \\
\text { Precrisis Level }\end{array}$ \\
\cline { 2 - 5 } & 117 & -66 & Q3 2002 \\
\hline U.S. dollar value of industrial wages & 96 & -45 & -14 \\
Relative price of nontradables & 57 & -43 & -13 \\
Real effective exchange rate & & & -18 \\
\hline
\end{tabular}

Sources: Goskomstat; and Fund staff estimates.

Regarding links between the RER and other variables, we note that the RER and oil prices seem to have moved roughly together since 1994, although with lags and by different magnitudes (see Figure 2). For instance, the oil price increase during 1994-96 was followed by a real appreciation. Again, oil prices declined sharply between 1997 and the first quarter of 1998, and the RER depreciated by more than 40 percent after August 1998. Finally, after the crisis, the sharp pickup in oil prices has been accompanied by a more limited real appreciation.

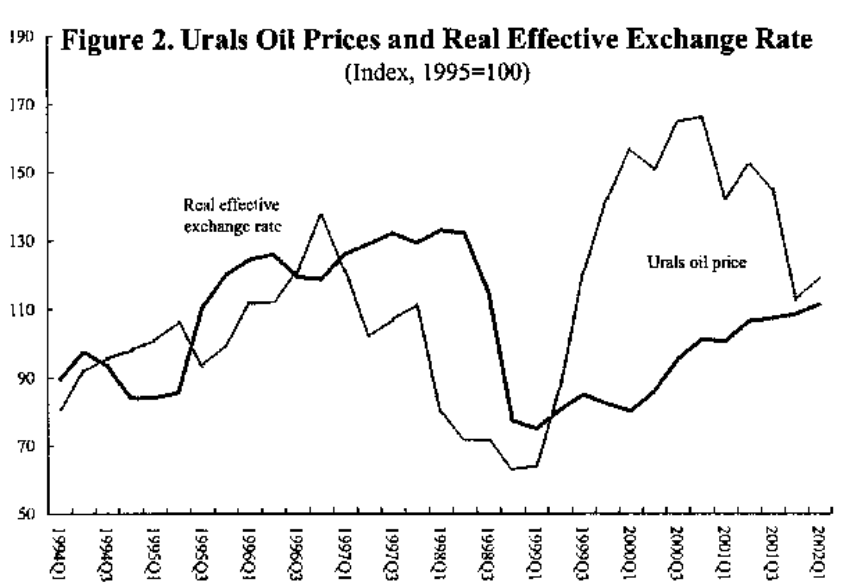


Turning to productivity, before the crisis a steady if relatively slow productivity growth rate was accompanied by steady real appreciation. Likewise, after the crisis, fast productivity growth was accompanied by fast real appreciation. However, the RER collapse during the crisis far exceeded any movement in productivity (see Figure 3).

Overall, this suggests the empirical analysis will face two challenges. First, explaining the timing and magnitude of the 1998 RER collapse; this may only be achievable by using a crisis or structural break dummy. Second, accounting for why the post-crisis appreciation was not even faster than observed. One option, discussed earlier, is to consider reserve accumulation. As seen in Figure 4, the post-crisis increase in oil prices was accompanied by a rapid increase in foreign exchange reserves, which could plausibly have dampened the pressure for nominal and perhaps real appreciation.
Figure 3. Relative Productivity and Real Effective Exchange Rate (Index, 1995=100)

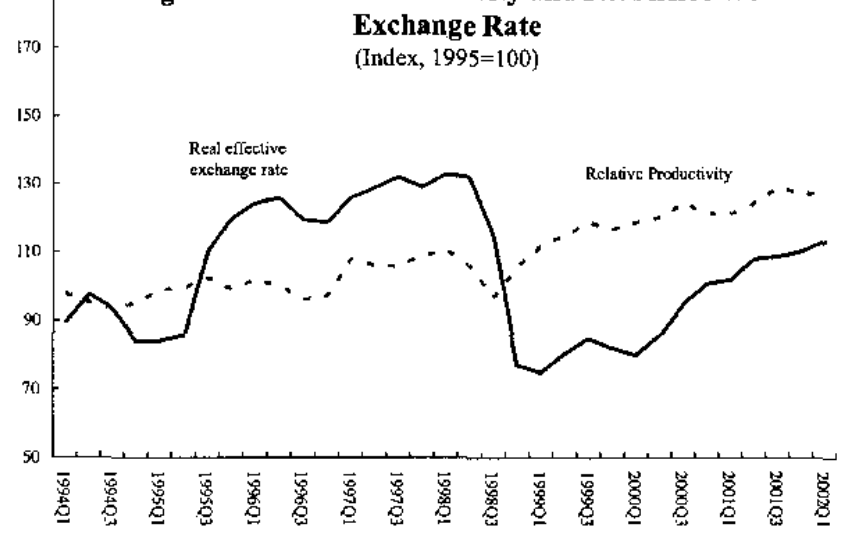

\section{ESTIMATION AND RESULTS}

We now present the results of estimating the model outlined in Section III, and compare the results of our study with those of other studies for transition economies and commodity-exporting countries. We must emphasize that, given the significant uncertainties involved in specifying and estimating this sort of model, particularly in the context of a transition economy, we feel free to engage in a broad specification search, and in particular drop several variables that prove to have the wrong sign. This should be borne in mind when examining the reported standard errors.

To estimate the long-run co-integrating relationship, we use the Phillips-Loretan estimator. ${ }^{5}$ This procedure is appealing in that it offers both a direct way to test the underlying economic theory, and simultaneous estimation of the short- and long-run coefficients. However, the

${ }^{5}$ For details, see Phillips and Loretan (1991). 
procedure does require all variables to have the same order of integration. Therefore, we first check the order of integration of the real exchange rate, oil prices and productivity using the Dickey-Fuller and Phillips-Peron tests. The results (see Table 2 below) suggest that we cannot reject the null that all three variables are I(1). Of course, such tests have to be treated with caution since in short samples they have extremely low power against economically relevant alternatives.

Table 2. Unit Root Tests

Null Hypothes/s: URALS has a unit root Lag Length: 2 (Automatic based on $S I C, M A X L A G=9$ )

\begin{tabular}{lccc} 
& & t-Statistic & Prob. ${ }^{*}$ \\
\hline \hline Augmented Dickey-Fuller test statistlc & -0.146803 & 0.6261 \\
\hline Test critical values: & $1 \%$ level & -2.630762 & \\
& $5 \%$ level & -1.950394 & \\
\hline
\end{tabular}

Null Hypothesis: URALS has a unit root

Bandwidth: 4 (Newey-West using Bartlett kernel)

\begin{tabular}{lccc} 
& & Adj. t-Stat & Prob. $^{*}$ \\
\hline \hline Phillips-Perron test statistic & -1.935180 & 0.3131 \\
\hline Test critical values: & $1 \%$ level & -3.626784 & \\
& $5 \%$ level & -2.945842 & \\
\hline \hline
\end{tabular}

Null Hypothesis: PRODUCTIVITY has a unit root Lag Length: 2 (Automatic based on SIC, MAXLAG=9)

\begin{tabular}{lccc} 
& & & \\
\hline & & t-Statistic & Prob.* $^{*}$ \\
\hline \hline Augmented Dickey-Fuller test statistic & 0.607692 & 0.9876 \\
\hline Test critical values: & $1 \%$ level & -3.670170 & \\
& $5 \%$ level & -2.963972 & \\
\hline
\end{tabular}

Null Hypothesis: PRODUCTIVITY has a unit root Bandwidth: 31 (Newey-West using Bartlett kernel)

\begin{tabular}{|c|c|c|c|}
\hline & & Adj, t-Stat & Prob. ${ }^{*}$ \\
\hline \multicolumn{2}{|c|}{ Phillips-Perron test statistic } & 0.782416 & 0.9921 \\
\hline Test critical values: & $\begin{array}{l}1 \% \text { level } \\
5 \% \text { level }\end{array}$ & $\begin{array}{l}-3.653730 \\
-2.957110 \\
\end{array}$ & \\
\hline
\end{tabular}

Null Hypothesis: Real effective exchange rate has a unit root Lag Length:2 (Automatic based on SIC, MAXLAG=9)

\begin{tabular}{lccc} 
& & \\
\hline \hline & t-Statistic & Prob. \\
\hline \hline Augmented Dickey-Fuller test statistic & -2.263522 & 0.1897 \\
\hline Test critical values: & $1 \%$ level & -3.670170 & \\
& $5 \%$ level & -2.963972 & \\
\hline \hline
\end{tabular}

Null Hypothesis: Real effective exchange rate has a unit root Bandwidth: 1 (Newey-West using Bartlett kernel)

\begin{tabular}{lccc}
\hline \hline & & Adj. t-Stat & Prob. $^{*}$ \\
\hline \hline Phillips-Perron test statistic & -1.773892 & 0.3859 \\
\hline Test critical values: & 1\% level & -3.661661 & \\
& $5 \%$ level & -2.960411 & \\
\hline \hline
\end{tabular}


In line with the methodology described above, we decompose the fitted RER into the ERER and into transitory factors. The latter include the short-term effect of monetary, exchange rate, and fiscal policy. In contrast, the ERER only incorporates the impact of changes in productivity and Urals oil prices, as well as the structural break dummy.

In order to understand the estimation results, it is useful to start by discussing the estimated long-run cointegrating relationship between the ERER and its underlying determinants, shown in Table 3 below. The estimated long-run coefficients have the anticipated signs and are statistically significant. In particular, the long-run elasticity with respect to productivity is approximately 1.3 , which is higher than typically found in other studies. The long-run elasticity with respect to oil prices is 0.31 , which implies a RER elasticity with respect to the overall terms of trade of about 0.8 , well within the range typically reported.

Table 3. Long-Run Cointegrating Relationship 1/

\begin{tabular}{lcccc}
\hline & & & & Post-Crisis \\
& Constant & Productivity & Urals Oil Prices & Structural Break \\
\hline Phillips-Loretan single equation ECM & 3.30 & 1.30 & 0.31 & -0.62 \\
& $(0.53)$ & $-(0.46)$ & $(0.12)$ & $(0.13)$ \\
\hline
\end{tabular}

1/ Standard errors in brackets.

We suspect these estimates may be distorted by three problems. First, oil prices are not a perfect proxy for the terms of trade. Second, our chosen policy variables, discussed below, may represent only part of the mechanism through which the response of the RER to oil prices in the post-crisis period was muted. Third, and linked, it may be hard to disentangle the separate effects of productivity and oil prices, given that they both grew strongly after the crisis. Overall, the result of these problems may well be that the coefficient on oil prices is biased downwards, and possibly that some of the impact of oil prices is wrongly attributed to productivity.

Subject to these caveats, and as expected, both productivity and oil prices clearly plays an important role in explaining movements of the ERER over extended periods. To quantify the economic significance of these factors, we now compute the contribution of productivity and of oil prices to the ERER appreciation between end-1998 and end-2001. The estimated long-run coefficients imply that productivity accounts for roughly 60 percent, and oil prices for 40 percent, of the appreciation of the ERER.

One should be extremely cautious in interpreting all these results, because the structural break dummy is statistically extremely significant, and also very large. The estimated hemi-elasticity of around 0.6 implies an almost 50 percent drop in the fitted RER 
immediately after the crisis, even after controlling for all observable fundamentals. To the extent that the dummy reflects (at least partly) post-crisis RER undershooting, rather than pre-crisis overvaluation, this sharp drop is likely to be corrected in the future. ${ }^{6}$ The critical problem is that, in the absence of forward-looking information such as that incorporated into the next section, it is hard to gauge what weight to attach to different interpretations of the dummy.

Since the beginning of 1999, the overall fitted RER appreciated less than the ERER, reflecting two factors. First, monetary policy, as proxied by the share of reserves in imports, was somewhat successful in the short-term in slowing real appreciation. Second, the RER only adjusts with some lag towards its equilibrium level, likely reflecting real rigidities in the economy. The estimated speed-of-adjustment coefficient implies that, after two quarters, about 70 percent of a shock to the RER has been absorbed. ${ }^{7}$ At this stage, we also note that the estimated coefficients on both excess credit and fiscal policy are insignificant. The former finding suggests that foreign exchange intervention (even if sterilized) may successfully retard real appreciation; the latter finding may not be surprising in view of the offsetting effects of the considerable tightening of fiscal policy, as discussed earlier.

Over the medium term, falling oil prices will act to reduce the ERER. Assume a medium-term world oil price of \$21/barrel (based on IMF WEO forecasts from before the Iraq crisis erupted). This implies that Russian oil prices will decline from the 2002 value of $\$ 22.4 /$ barrel (CIF) to $\$ 20.1 / \mathrm{barrel}(\mathrm{CIF})$, roughly a 10.3 percent decline. Assume further that Russian natural gas prices move in line with oil prices. Abstracting from the role of ongoing productivity growth, which is discussed below, our earlier results imply that the 2002 RER will be roughly 13 percent below the long-run ERER. However, there is significant uncertainty about future oil prices. To quantify its impact on the long-run ERER, we consider two scenarios: first, a decline in the Urals oil price to $\$ 17 /$ barrel; second, an increase in the oil price to $\$ 23 /$ barrel. Together, these scenarios imply that the 2002 RER might range from 9 percent to 17 percent below the long-run ERER.

\footnotetext{
${ }^{6}$ We tried including a pure "August 1998 crisis dummy," but this was not significant after controlling for the structural break.
}

${ }^{7}$ The speed of adjustment (the coefficient on the disequilibrium term) and the elasticity with respect to monetary policy are given in the following equation, which shows the full dynamics:

$$
\Delta \ln e_{t}=\frac{0.49}{(0.09)}\left(\ln e^{*} t-\ln e_{t-1}\right)-\frac{0.07}{(0.05)} \mathrm{d} \ln \left(\text { Reserves }_{t} / \text { Imports }_{t}\right)-\frac{0.31}{(0.12)} \mathrm{d} \ln \left(\text { Urals }_{t-2}\right)+v_{t},
$$

where Reserves is gross reserves in dollars, Imports is nominal dollar imports, Urals is Urals oil price, and numbers in parentheses denote standard errors. 
Returning now to the impact of long-run productivity growth, our results suggest the presence of a strong Balassa-Samuelson effect. The significance of this lies in the fact that such an effect should not be resisted by monetary policy. Over the last three years, average labor productivity growth in Russia was approximately 4.5 percent, implying a 2-3 percentage point productivity growth differential vis-à-vis the OECD. Assuming that as a result of structural reforms the productivity growth differential will remain 2-3 percentage points, in the long-run the ERER will also continue growing by perhaps $2-3$ percent per annum (since the coefficient linking the ERER to relative productivity is close to unity).

Finally, the estimation results remain broadly stable, or indeed improve in significance, if one uses alternative measures of the RER. For instance, replacing the CPI-based REER with U.S. dollar wages still implies a large, significant ERER elasticity with respect to productivity, and it raises the significance level of the estimated coefficients on oil prices and on monetary policy.

\section{NORMATIVE APPROACH: LeSSONS FROM THE EXPERIENCE OF OTHER ECONOMIES}

The methodology employed so far, while extremely popular, relies on two crucial assumptions. First, that a stable relationship between the RER and its underlying determinants can be gleaned from historical data. Second, that this relationship will continue to hold in the future. In the case of an economy like Russia, where the transition process is still very much underway, and given the clear evidence for an in-sample structural break, such assumptions need to be treated cautiously. In particular, the methodology cannot be fruitfully used to discuss the current or future level of the ERER.

Hence, we now carry out some alternative calculations, based on the experience of three groups of countries:

- $\quad$ The advanced transition economies (the Czech Republic, Estonia, Hungary, Latvia, Lithuania, Poland, the Slovak Republic, and Slovenia).

- Resource-rich economies (Chile, Indonesia, Kazakhstan, Mexico, Nigeria, Norway, Saudi Arabia, South Africa, the United Kingdom, and Venezuela).

- Nontransition emerging markets (Argentina, Brazil, China, Korea, Malaysia, Mexico, South Africa, Thailand, and Turkey).

Our calculations, which are loosely based on Williamson's "fundamental equilibrium exchange rate" approach, broadly update and extend some of the work carried out in the IMF's Staff Country Report No. 02/75.

On the whole, the other transition economies likely represent the single best comparator, given the extent of the structural transformations that Russia has already undergone, and will undergo in the future. However, the experience of resource-rich economies may also be of 
interest, given Russia's reliance on natural resource output and exports. We view the non-transition emerging markets as a priori least relevant, but nevertheless analyze them to determine the robustness of our results. In all cases, we focus on developments in the 1990's. Previous decades are less relevant, because globalization and increases in private capital flows are likely to have implications for the sort of external deficit that can be financed.

Overall, Russia's external current account should be expected to converge in the long run to a deficit of 1-3 percent of GDP, assuming continued progress on structural reforms. As a starting point, we note that, in advanced transition economies, current account deficits of 4-6 percent of GDP have been sustained for extended periods, ${ }^{8}$ but they lately seem to have started converging towards lower levels. Given Russia's extraordinary natural-resource wealth, it might well experience even higher levels of foreign direct investment than most transition economies. On the other hand, Russia's experience with large capital flight and the possibility that future capital flows will be highly volatile suggest the need for caution.

Current account deficits have, on average, been much lower in the nontransition emerging markets and in resource-rich economies. ${ }^{9}$ However, these groups are much more heterogeneous. In particular, some of these economies have experienced exchange rate crises and "sudden stops" in capital inflows, leading to the emergence of large current account surpluses (e.g., Indonesia and Korea). Other countries, such as Norway, are saving in the expectation of dwindling natural-resource exports, an issue that is not expected to arise in Russia for a significant period yet. Overall, it still remains true that in several of these economies, including for instance Chile and Mexico, current account deficits larger than our target have proved sustainable. ${ }^{10,11}$

Our assumptions for the long-run current account imply a deterioration of 9-11 percent of GDP from the projected surplus of 8.1 percent of GDP in 2002. Part of this deterioration can be absorbed through slower growth in external reserves, but private capital inflows will

${ }^{8}$ For example, over the last 4 years for which data is available, their average current account deficit equaled 6.2 percent of GDP.

${ }^{9}$ Since 1995 , non-transition emerging markets ran an average current account deficit of 0.3 percent of GDP, resource-rich economies an average surplus of 0.1 percent of GDP.

${ }^{10}$ Mexico did run significant surpluses in the mid-1980's, but this reflected the short-run impact of its debt default on capital flows.

${ }^{11}$ Demographics is another, potentially important determinant of the sustainable current account balance. While Russia has experienced over the last decade significant declines in fertility and increases in mortality, these developments were likely related to the collapse in output and income since the transition began. One would therefore expect that they will be reversed in the near future. 
also have to increase significantly. For instance, FDI would have to increase by at least a further 1-2 percent of GDP.

This current-account deterioration will in part occur automatically, as world energy prices decline from their high levels. Assume again a medium-term world oil price of $\$ 21 /$ barrel, so that Russian oil prices decline from the 2002 value of $\$ 22.4 /$ barrel (CIF) to $\$ 20.1 /$ barrel (CIF). Assume further that Russian natural gas prices move in line with oil prices. Ceteris paribus, all this implies a current-account deterioration of 1.7 percent of GDP (or $\$ 5.7$ billion).

Even allowing for a medium-term world oil price decline, and even after the estimated 4.5 percent real appreciation in 2002, we conclude that the RER will have to appreciate so as to bring about a further current-account deterioration of 7.4-9.4 percent of GDP (or $\$ 26$ billion- $\$ 33$ billion). In turn, the precise magnitude of the required appreciation hinges on the price elasticities of imports and exports.

We postulate an import demand relationship of the type

$$
m=\alpha+\beta y+\gamma z+\delta \text { Other }+\varepsilon,
$$

where $m$ are real imports, $y$ is real GDP, $z$ is the RER (an increase in the RER is appreciation; all variables are in logarithms), Other includes any other controls, such as crisis dummies, and $\varepsilon$ is a random term. The estimation results, in error-correction form and with standard errors in parentheses, are:

$$
\begin{aligned}
& \Delta m_{t}=0.09 \text { Aug98Dummy }+3.47 \Delta y_{t}+\quad 0.48 \quad\left(0.58 y_{t-1}+\quad 0.79 z_{t-1}-m_{t-1}\right) \\
& (0.03)
\end{aligned}
$$

Most relevant to us here is the long-run elasticity of imports with respect to the RER, equal to 0.79 . Regarding export demand, we have been unable to specify and estimate a satisfactory relationship. Instead, we simply assume the same price elasticity of -0.324 estimated by Reinhart (1995) in a pooled regression for $12 \mathrm{LDC}$.

Then, given the projected 2002 exports and imports (amounting, respectively, to 31.8 percent and 23.7 percent of GDP), we calculate that a one percent RER appreciation yields a long-run current account deterioration of 0.29 percent of GDP (or $\$ 1$ billion). Hence, the implied long-run real appreciation lies in the range 26-33 percent from the estimated 2002 level.

Given the uncertainty about the price-elasticity of imports and in particular exports, it is crucial to engage in sensitivity analysis with respect to these variables. A natural upper bound is to assume that both import and export volumes are unit-price-elastic. Then, the implied long-run real appreciation lies in the range 13-17 percent from the projected 2002 level, or less than half as much as previously calculated. This value would imply that 
the RER will roughly return to its level in July 1998, just before the crisis-even though both productivity and oil prices were much lower then.

So far, we have assumed a long-run oil price of $\$ 20.1 /$ barrel. Given the uncertainty associated with this variable, we also consider three alternative scenarios: a "high" long-run oil price of $\$ 23 /$ barrel, a "low" price of $\$ 17 /$ barrel, and a "very low" price of $\$ 10 /$ barrel. Our calculations imply that each $\$ 1$ increase in the long-run oil price, relative to the central scenario, yields an additional 1.3 percent long-run real appreciation. ${ }^{12}$ Put differently, the long-run elasticity of the RER with respect to world oil prices equals $0.26,{ }^{13}$ so that the elasticity with respect to the overall terms of trade equals about 0.62 , almost equal to the value used in the previous section. Hence, at "high" oil prices, the implied real appreciation lies in the range 17-21 percent; at "low" oil prices, the implied real appreciation lies in the range 9-13 percent; and, at "very low" oil prices, there is almost no implied real appreciation. All these results are summarized in Table 4.

Table 4. Real Exchange Rate in 2002: Percent Undervaluation, Under Various Assumptions

\begin{tabular}{lcc}
\hline & $\begin{array}{c}\text { Price Elasticity Of } \\
\text { Imports }=1 ; \\
\text { Exports }=-1\end{array}$ & $\begin{array}{c}\text { Price Elasticity Of } \\
\text { Imports }=0.79 ; \\
\text { Exports }=-0.324\end{array}$ \\
\hline Potential long-run Russian oil price $(\$ 20.1 / \mathrm{bbl})$ & $\mathbf{1 3 - 1 7}$ & $26-33$ \\
Very low long-run oil price $(\$ 12 / \mathrm{bbl})$ & $0-4$ & $0-7$ \\
Low long-run oil price $(\$ 17 / \mathrm{bbl})$ & $9-13$ & $18-25$ \\
High long-run oil price $(\$ 23 / \mathrm{bbl})$ & $17-21$ & $33-40$ \\
\hline
\end{tabular}

Regarding the impact of productivity growth on the RER, De Broeck and Sløk (2001) have analyzed in detail the experience of transition economies. Overall, they conclude that "an increase in the relative productivity differential of one percent leads to an increase in the

${ }^{12}$ To compute this, we consider the marginal impact of an increase in oil prices on net energy exports, divided by the marginal impact of an increase in the RER on the current account. For simplicity, the former impact is computed under the assumption of exogenous energy export volumes; hence, the coefficient is likely to represent a lower bound.

${ }^{13}$ This is computed at the assumed long-run oil price of $\$ 20.1 /$ barrel. 
exchange rate of approximately 0.4 percent."14 This is a somewhat lower value than the one estimated in the previous section, and provides a useful lower bound against which to check our earlier calculations.

For the period 1991-99, estimates based on extending the dataset in De Broeck and Koen (2000) suggest that annual TFP growth rates in advanced transition economies averaged just over 2 percent per annum. However, there were large variations: for instance, Poland enjoyed TFP growth rates of almost 4 percent per annum. Hence, Russian productivity growth might well exceed the average value in its trading partners by $2-3$ percentage points per annum, even for an extended period. In turn, this implies that, even after the RER has appreciated to its long-run equilibrium value, it may be expected to continue growing by a further 1 percent per annum.

\section{Conclusions}

Any analysis of equilibrium RER is subject to large uncertainties. However, empirical analysis confirms a link between the ERER and productivity, in both Russia and other transition economies. Some dependence of the Russian ERER on oil prices can also be observed, in spite of the attempts to offset such links through monetary policy and foreign reserve accumulation; the dependence is likely to become even clearer over the long run.

Looking ahead, it appears likely that Russia will experience, and should indeed target, a significant current account deterioration in the medium term, over and above what is implied by likely changes in world oil prices. A further, significant real appreciation will be required to bring about this outcome. Our estimates suggest that we might expect a real appreciation of more than 10 percent, with some parameterizations yielding more than 30 percent. However, the estimated exchange rate disequilibrium remains very sensitive to the assumed long-run oil prices.

Over the long run, and even after any RER disequilibrium is resolved, the link between the ERER and productivity implies that we should expect both the actual and the equilibrium RER to continue appreciating. The precise rate of productivity-driven appreciation will depend on the speed and determination with which structural reforms are pursued; on average, it has equaled about 1 percent per annum in other transition economies.

To the extent that the authorities resist nominal appreciation, the real appreciation discussed above would have to occur through increases in domestic prices, particularly of nontradables, and would also show up as higher consumer prices index (CPI) inflation. It should be

\footnotetext{
${ }^{14}$ They can only find tentative evidence of a Balassa-Samuelson effect in Russia and other FSU economies. However, this finding likely reflects the fact that their sample stops in 1998, and thus cannot incorporate the experience of the recent period of real appreciation and productivity growth.
} 
emphasized that such appreciation, whether reflecting an adjustment to the current disequilibrium or the response to continuing productivity growth, should not be viewed as a threat to growth, employment, or external sustainability. Rather, it represents a mechanism which ensures that the Russian people will achieve a standard of living commensurate with their productivity and external environment. The paper did not tackle the question of the optimal speed of RER adjustment, but we would like to finish by emphasizing the standard conclusion that such adjustment could proceed relatively rapidly, so long as (a) structural reforms are pursued diligently, so as to reduce the extent of structural rigidities in the economy; and (b) output, employment rates, and capacity utilizations do not show signs of precipitous declines. 


\section{REFERENCES}

Clarida, R., and J. Gali, 1994, "Sources of Real Exchange Rate Fluctuations: How Important Are Nominal Shocks," NBER Working Paper No. 4658 (Cambridge, Massachusetts: National Bureau of Economic Research).

Clark, P., 1994, Exchange Rates and Economic Fundamentals: A Framework for Analysis, IMF Occasional Paper No. 115 (Washington: International Monetary Fund).

Clark, Peter B., and R. MacDonald, 1999, "Exchange Rates and Economic Fundamentals: A Methodological Comparison of BEERs and FEERs," in Equilibrium Exchange Rates, ed. by R. MacDonald, and J. Stein (Boston, Massachusetts: Kluwer Academic Publishers).

- 2000, "Filtering the BEER: A Permanent and Transitory Decomposition," IMF Working Paper 00/144 (Washington: International Monetary Fund).

De Broeck, M., and V. Koen, 2000, "The Great Contraction in Russia, the Baltics and the Other Countries of the Former Soviet Union: A View from the Supply Side," IMF Working Paper 00/32 (Washington: International Monetary Fund).

De Broeck, M., and T. Sløk, 2001, "Interpreting Real Exchange Rate Movements in Transition Countries," IMF Working Paper 01/56 (Washington: International Monetary Fund).

Edwards, S., 1985, "Commodity Export Prices and the Real Exchange Rate in Developing Countries: Coffee in Colombia," NBER Working Paper No. 1570 (Cambridge, Massachusetts: National Bureau of Economic Research).

_- 1986, "Real Exchange Rate Variability: an Empirical Analysis of the Developing Countries Case," NBER Working Paper No. 1930 (Cambridge, Massachusetts: National Bureau of Economic Research).

- 1989, Real Exchange Rates, Devaluations and Adjustment: Exchange Rate Policy in Developing Countries (Cambridge, Massachusetts: MIT Press).

_ 1994, "Real and Monetary Determinants of Real Exchange Rate Behavior: Theory and Evidence from Developing Countries," Chapter 4 in Estimating Equilibrium Exchange Rates, ed. by J. Williamson (Washington: Institute for International Economics, 1994).

Elbadawy, I., 1994, "Estimating Long-Run Equilibrium Real Exchange Rates," Chapter 5 in Estimating Equilibrium Exchange Rates, ed. by J. Williamson (Washington: Institute for International Economics, 1994). 
Faruqee, H., 1995, "Long-Run Determinants of the Real Exchange Rate: A Stock-Flow Perspective," Staff Papers, International Monetary Fund, Vol. 42 (March), pp. 80-107.

Feyzioglu, T., 1997, "Estimating the Equilibrium Real Exchange Rate: An Application to Finland," IMF Working Paper 97/109 (Washington: International Monetary Fund).

Hinkle, L. E., and P. J. Montiel, ed., 1999, Exchange Rate Misalignment: Concepts and Measurement for Developing Countries (Oxford University Press).

International Monetary Fund (IMF), 2002, Russian Federation: Selected Issues and Statistical Appendix, IMF Staff Country Report No. 02/75. Available via the Internet: http://www.imf.org/external/pubind.htm.

Isard, P., and H. Faruqee, 1998, "Exchange Rate Assessment: Extensions of the Macroeconomic Balance Approach,” IMF Occasional Paper No. 167 (Washington: International Monetary Fund).

- G. Russell Kincaid, and M. Fetherston, 2001, "Methodology for Current Account and Exchange Rate Assessments," IMF Occasional Paper No. 209 (Washington: International Monetary Fund).

Kahn, M., and J. Ostry, 1991, "Response of the Equilibrium Real Exchange Rate to Real Disturbances in Developing Countries," IMF Working Paper WP/91/3 (Washington: International Monetary Fund).

Lane, Philip R., and Gian Maria Milesi-Ferretti, 2001, "The External Wealth of Nations: Measures of Foreign Assets and Liabilities for Industrial and Developing Countries," Journal of International Economics, Vol. 55 (December), pp. 263-94.

— 2002, "Long-Run Determinants of the Irish Real Exchange Rate," Applied Economics, Vol. 34 (March), pp. 549-53.

__ 2002b, "External Wealth, The Trade Balance, and the Real Exchange Rate," European Economic Review, Vol. 46 (June), pp. 1049-71.

MacDonald, R., 1995, “Long-Run Exchange Rate Modeling: A Survey of Recent Evidence," Staff Papers, International Monetary Fund, Vol. 42 (September), pp. 437-98 (Washington: International Monetary Fund). and L. Ricci, 2002, "Estimation of the Equilibrium Real Exchange Rate for South Africa," forthcoming IMF Working Paper (Washington: International Monetary Fund).

MacDonald, R., and J. Stein, 1999, Equilibrium Exchange Rates (Boston, Massachusettes: Kluwer Academic Publishers). 
Mongardini, J., 1998, "Estimating Egypt's Equilibrium Real Exchange Rate,” IMF Working Paper 98/5 (Washington: International Monetary Fund).

Paiva, C., 2001, "Competitiveness and the Equilibrium Exchange Rate in Costa Rica," IMF Working Paper 01/2 (Washington: International Monetary Fund).

Phillips, P.C.B., and M. Loretan, 1991, "Estimating Long-run Economic Equilibria," Review of Economic Studies, Vol. 58, pp. 407-436.

Reinhart, C., 1995, "Devaluation, Relative Prices, and International Trade," Staff Papers, International Monetary Fund, Vol. 42 (June), pp. 290-312 (Washington: International Monetary Fund).

Williamson, J., ed., 1994, Estimating Equilibrium Exchange Rates (Washington: Institute for International Economics). 